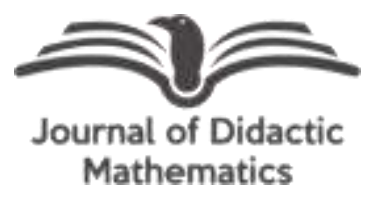

\title{
Upaya peningkatan kemampuan pemecahan masalah matematika siswa melalui pembelajaran contextual teaching and learning pada materi peluang kelas XI SMA Negeri 21 Medan
}

\author{
Indriyani \\ SMA N 21 Medan, Medan, Sumatera Utara, Indonesia, 20228
}

\section{Suwanto*}

STKIP Asy-Syafi'iyah Internasional Medan, Medan, Sumatera Utara, Indonesia, 20144

*Corresponding Author: suwantompd89@gmail.com

\begin{abstract}
This research is a classroom action research, which aims to look at students' mathematical problem-solving abilities and student mathematics learning outcomes by applying the Contextual Teaching and Learning model in class XI IPA-1 SMA Negeri 21 Medan. The research subjects were 35 students. At the beginning of the study, observations were made to find out the weaknesses of students and the problems faced when teaching and learning activities took place. In addition to the data of mathematical problem-solving abilities that were analyzed, student learning activities were also analyzed. Based on the research results obtained observations in the first cycle; writing/reading $(35.67 \%)$, working on student worksheets $(23.33 \%)$, asking fellow friends $(22 \%)$, asking teachers $(12.33 \%)$, and activities not relevant to teaching and learning activities $(6.67 \%)$. In the second cycle obtained writing/reading $(28.3 \%)$, working on student worksheets $(28 \%)$, asking fellow friends $(24 \%)$, asking teachers $(18.7 \%)$, and activities not relevant to teaching and learning activities $(1 \%)$. The results for classical completeness obtained in the first cycle of $62.9 \%$, but in the second cycle of $85.7 \%$.
\end{abstract}

Historis Artikel:

Diterima: 27 Februari 2020

Direvisi: 4 Maret 2020

Disetujui: 27 Maret 2020

\section{Keywords:}

Problem solving ability, learning outcomes, learning activities

\footnotetext{
Sitasi: Indriyani., \& Suwanto. (2020). Upaya peningkatan kemampuan pemecahan masalah matematika siswa melalui pembelajaran contextual teaching and learning pada materi peluang kelas XI SMA Negeri 21 Medan. Journal of Didactic Mathematics, 1(1), 8-15. https://doi.org/10.34007/jdm.v1i1.146
}

\section{PENDAHULUAN}

Salah satu harapan yang ingin dicapai dalam pembelajaran matematika di Sekolah Menengah Atas (SMA) berdasarkan kurikulum yang berlaku pada saat ini adalah dimilikinya kemampuan berpikir matematik. Istilah berpikir matematik memuat arti cara berpikir yang berkaitan dengan karakteristik matematik. Oleh karena itu, pembahasan tentang berpikir matematik berkaitan erat dengan hakikat matematik itu sendiri.

Sumarmo (2005) mengemukakan bahwa pendidikan matematika pada hakikatnya mempunyai dua arah pengembangan yaitu untuk memenuhi kebutuhan masa kini dan kebutuhan masa yang akan datang. Kebutuhan masa kini yang dimaksud yaitu mengarahkan pembelajaran matematika untuk dan ide matematika yang kemudian diperlukan untuk menyelesaikan masalah matematika dan ilmu pengetahuan lainnya. Sedangkan yang dimaksud dengan kebutuhan masa yang akan datang adalah pembelajaran matematika memberikan kemampuan menalar yang logis, sistematik, kritis dan cermat, menumbuhkan rasa percaya diri, dan rasa keindahan terhadap keteraturan sifat matematika, serta mengembangkan sikap objektif dan terbuka yang sangat diperlukan dalam menghadapi masa depan yang senantiasa berubah.

Sementara itu, kenyataannya para siswa masih merasa asing untuk membicarakan matematika, yang merupakan akibat sangat jarangnya para guru memberikan kesempatan para 
Upaya peningkatan kemampuan pemecahan masalah matematika siswa melalui pembelajaran...

siswa untuk mengemukakan atau menjelaskan gagasan atau ide-idenya. Hal ini sejalan dengan apa yang dikemukakan Cai (1996) yang menyatakan bahwa sebagai akibat dari sangat jarangnya para siswa dituntut untuk menyediakan penjelasan dalam pelajaran matematika, mengakibatkan para siswa merasa sangat asing untuk berbicara tentang matematika, dengan demikian menjadi mengejutkan bagi mereka untuk memberikan pertimbangan atas jawabannya. Sehingga tidak heran jika ditemukan hasil belajar siswa SMA Negeri 21 Medan rendah. Berdasarkan hasil berlajar matematika siswa dan analisis kemampuan pemecahan masalah matematis siswa. dapat disimpulkan kemampuan pemecahan masalah matematis siswa rendah hal ini mengakibatkan dari 35 siswa yang dapat menuntaskan KKM hanya 5 orang atau sekitar 14,29\% orang. Jumlahnya kurang dari ketuntasan secara klasik sebesar $80 \%$ dari seluruh jumlah siswa.

Rendahnya kemampuan pemecahan masalah siswa bisa terjadi dikarenakan metode pembelajaran yang diterapkan oleh guru bidang studi masih kurang tepat. Berdasarkan observasi, metode pembelajaran yang diterapkan oleh guru matematika adalah metode ceramah. Penggunaan metode ini membuat pembelajaran didominasi oleh guru, akibatnya siswa menjadi pasif dalam belajar dan cenderung sebagai penerima saja. Lie (2008:3) menyatakan bahwa“"Tuntutan dalam dunia pendidikan sudah banyak berubah. Kita tidak bisa lagi mempertahankan paradigma lama bahwa jika seseorang mempunyai pengetahuan dan keahlian dalam suatu bidang, dia pasti dapat mengajar. Banyak guru masih menganggap paradigma lama ini satu-satunya alternatif. Mereka mengajar dengan metode ceramah mengharapkan siswa Duduk, Diam, Dengar, Catat dan Hafal (3DCH) serta mengadu siswa satu sama lain."

Faktor yang menyebabkan rendahnya tingkat kemampuan pemecahan masalah merupakan salah satu faktor yang menyebabkan hasil belajar matematika siswa rendah, karena matematika sangat erat kaitannya dengan tingkat kemampuan pemecahan masalah matematika siswa. Hal tersebut dijelaskan oleh Tumudi (2008:29) "Problem solving (pemecahan masalah) dalam pembelajaran matematika merupakan bagian yang tak terpisahkan dalam pembelajaran matematika". Ada banyak pendekatan pembelajaran yang bisa kita gunakan dalam upaya menumbuhkembangkan kemampuan pemecahan masalah matematika tersebut, salah satu pendekatan yang diduga akan sejalan dengan karakteristik matematika dan harapan kurikulum yang berlaku pada saat ini adalah pendekatan kontekstual yang biasanya disebut juga dengan CTL (Contextual Teaching and Learning), melalui model pembelajaran kontekstual ini diharapkan siswa lebih memahami konsep-konsep matematika yang diberikan dalam pembelajaran, dan tahu kegunaannya.

Pembelajaran CTL adalah suatu sistem pengajaran yang didasarkan pada alasan bahwa pengertian atau makna muncul dari hubungan antara konten dan konteks. Konteks memberi makna pada konten. Pemahaman yang lebih terhadap suatu konten dapat dicapai siswa jika diberikan konteks yang lebih luas di mana didalamnya siswa dapat membuat hubungan-hubungan. Jadi bagian penting dari pekerjaan guru adalah menyediakan konteks. Semakin banyak siswa mengaitkan pelajaran mereka dengan konteks maka akan lebih banyak pengertian yang dapat diturunkan dari pelajaran tersebut. Menentukan makna atau pengertian dalam pengetahuan dan keterampilan mengarahkan pada penguasaan pengetahuan dan keterampilan-keterampilan.

Berdasarkan kedua pernyataan di atas dapat diketahui bahwa pembelajaran kontekstual ini merupakan sebuah pendekatan pembelajaran yang menekankan pada pembelajaran bermakna, dan belajar di sekolah dikontekskan ke dalam situasi nyata, jadi lebih menekankan pada proses penemuan dari pengetahuan bukan pada hasil akhir. Selanjutnya, melalui pembelajaran kontekstual ini diharapkan dapat menumbuhkan minat dan motivasi belajar siswa, sehingga diharapkan adanya peningkatan hasil belajar siswa ke arah yang lebih baik, dan siswa akan terus merasakan manfaatnya. Dengan penggunaan konteks dalam belajar matematika, tentunya akan memberikan motivasi pada siswa, bahwa belajar matematika memiliki manfaat dan kegunaan yang sangat besar dalam kehidupan keseharian mereka.

Dalam pembelajaran yang menggunakan pendekatan kontekstual, guru harus mengkaitkan materi yang diajarkan dengan situasi dunia nyata siswa dan mendorong siswa untuk membuat 
hubungan antara pengetahuan yang dimilikinya dengan penerapannya dalam kehidupan mereka sehari-hari. Bagi guru yang kreatif, peristiwa-peristiwa yang terjadi di sekitar lingkungan belajar siswa dapat dijadikan sebagai inspirasi untuk menciptakan kondisi yang lebih konkrit guna menuntun siswa dalam memahami konsep matematika melalui model pembelajaran kontekstual. Bila pembelajaran matematika yang dilakukan menggunakan CTL, maka tentunya pembelajaran tersebut harus memiliki komponen-komponen yang dimiliki CTL. Komponen-komponen tersebut adalah konstruktivisme (constructivism), penemuan (inquiry), bertanya (questioning), masyarakat belajar (learning community), pemodelan (modeling), refleksi (reflection), penilaian yang sebenarnya (authentic assessment).

\section{METODE}

Jenis penelitian ini adalah penelitian tindakan kelas (classroom action research) yaitu penelitian tindakan (action research) yang dilakukan dengan tujuan memperbaiki mutu praktik pembelajaran di kelas. Karena penelitian ini bertujuan untuk mengungkap kendala dan kesulitan yang dialami siswa dalam menyelesaikan permasalahan yang berkaitan dengan materi peluang dan menjelaskan upayaupaya yang dilakukan untuk meningkatkan kemampuan pemecahan masalah matematik siswa pada materi peluang. Lokasi dilakukannya penelitian ini adalah di SMA Negeri 21 Medan, kelas XI dan pelaksanaannya pada semester genap, Tahun Pelajaran 2014/2015.

Objek dalam penelitian ini adalah penerapan model pembelajaran Contextual Teaching and Learning (CTL) untuk meningkatkan kemampuan pemecahan masalah siswa pada pokok bahasan peluang di kelas XI, alat pengumpulan data yang digunakan tes dan observasi. Instrumen tes digunakan untuk mengukur kemampuan siswa memecahkan masalah yang berupa tes dalam bentuk uraian dan terdiri dari 4 soal. Observasi yang dilakukan merupakan pengamatan terhadap seluruh kegiatan dan perubahan yang terjadi pada saat diberikan tindakan. Sedangkan untuk teknik analisis data, reduksi data meliputi pengkategorian dan pengklasifikasian data. Setelah diklasifikasikan, data dikelompokkan kemudian dilanjutkan pada penyimpulan. Kegiatan reduksi ini bertujuan untuk melihat kesalahan jawaban siswa dalam menyelesaikan soal-soal tentang luas permukaan dan volume peluang dan tindakan apa yang dilakukan untuk perbaikan kesalahan tersebut.

\section{HASIL DAN PEMBAHASAN}

Hasil ujian formatif yang telah dilakukan sebelumnya, dari 35 siswa hanya 5 orang siswa yang dapat tuntas dalam pembelajaran atau sekitar 14,28\% yang dapat menuntaskan KKM. Peneliti sebagai guru merasa pada saat pembelajaran, aktivitas positif terhadap pelajaran matematika rendah, karena siswa kurang memahami masalah yang dihadapi sehingga tidak dapat menyelesaikan penyelesaian masalahnya.Selain itu juga siswa tidak mau mengeluarkan ide, menganggap matematika itu membosankan, sulit karena banyak hafalan rumus-rumus matematika yang sangat sulit untuk dihafal. Rendahnya kemampuan pemecahan masalah matematika siswa berdampat negatif terhadap hasil belajar matematika siswa. Hal tersebut dapat dilihat dari hasil di bawah ini.

Tabel 1. Hasil Belajar Ujian Formatif

\begin{tabular}{ccccc}
\hline No & Data & Frekuensi & Persen $\mathbf{( \% )}$ & Keterangan \\
\hline 1 & $11-20$ & 3 & 8,57 & Belum Tuntas \\
\hline 2 & $21-30$ & 3 & 8,57 & Belum Tuntas \\
\hline 3 & $31-40$ & 9 & 25,71 & Belum Tuntas \\
\hline 4 & $41-50$ & 10 & 28,57 & Belum Tuntas \\
\hline 5 & $51-60$ & 5 & 14,29 & Belum Tuntas \\
\hline 6 & $61-70$ & 1 & 2,89 & Tuntas \\
\hline 7 & $71-80$ & 4 & 11,43 & Tuntas \\
\hline
\end{tabular}


Upaya peningkatan kemampuan pemecahan masalah matematika siswa melalui pembelajaran...

Deskripsi Siklus I

Berangkat dari hasil ujian formatif terdapat kelemahan-kelemahan kemampuan pemecahan masalah matematika siswa untuk itu dilakukan penelitian tindakan kelas. Oleh karena itu untuk menyelesaikan masalah-masalah yang dihadapai siswa dilakukan penelitian tindakan dimulai dari siklus I.

\section{Permasalahan}

Berdasarkan hasil observasi dan hasil ujian formatif, dapat diperoleh letak kesulitan siswa dalam menyelesaikan soal; (1) Siswa masih kurang mampu menuliskan informasi dengan tepat. Kebanyakan siswa masih menuliskan seluruh isi soal yang diberikan pada siswa. Hal ini dikarenakan siswa belum mampu mengerti apa yang dimaksud dari dari soal; (2) Siswa masih belum dapat mempresentasikan soal cerita yang diberikan lalu memodelkan dalam bentuk matematika; (3) Konsep yang digunakan dalam menyelesaikan masalah/soal masih belum tepat; (4) Idenya dalam menyelesaikan masalah yang diberikan masih monoton; (5) Kurang mengembangkan idenya dalam menyelesaikan masalah. Upaya yang dilakukan untuk meningkatkannya adalah dengan menerapkan model pembelajaran Contextual Teaching and Learning (CTL).

\section{Rencana Tindakan}

Untuk mengatasi rendahnya kemampuan pemecahan masalah matematika siswa, direncanakan pembelajaran dengan menerapkan model pembelajaran Contextual Teaching and Learning (CTL). Tindakan yang akan diambil adalah; (1) menyusun rencana pelaksanaan pembelajaran (RPP) yang berisikan langkah-langkah kegiatan dalam pembelajaran Contextual Teaching and Learning; (2) mempersiapkan sarana pendukung pembelajaran yang mendukung pelaksanaan tindakan seperti LKS; (3) mempersiapkan instrumen penelitian, seperti instrrumen tes dan observasi.

\section{Pelaksanaan Tindakan}

Pelaksanaan tindakan I terdiri dari tiga kali pertemuan untuk melaksanakan kegiatan pembelajaran sesuai RPP yang telah disusun sebagai berikut; (1) memberikan apersepsi kepada siswa dengan menyampaikan tujuan pembelajaran yang akan dicapai tiap pertemuan untuk membangkitkan motivasi belajar mereka; (2) menyajikan informasi kepada siswa dengan bantuan menjukkan media pembelajaran berupa gambar-gambar yang sudah dipersiapkan sebelumnya; (3) guru membimbing siswa memahami materi ajar melalui tanya jawab mengenai materi peluang dengan menekankan petunjuk-petunjuk yang ada pada Lembar Kegiatan Siswa; (4) guru memberikan contoh latihan soal cerita kemudian membimbing siswa menyelesaikannya; (5) guru membentuk kelompok diskusi; (6) memberikan soal cerita yang disajikan dalam LKS yang telah disiapkan kemudian menyuruh siswa untuk menunjukkan jawaban mereka masing-masing jika jawaban mereka berbeda-beda baik salah ataupun benar dan cara yang beragam untuk memperoleh jawaban mereka; (7) guru mengawasi diskusi kelompok supaya terjaga ketertibannya dan berjalan diskusi dengan baik; (8) guru meminta perwakilan kelompok tertentu untuk menyajikan temuannya di depan kelas. Guru bisa menjadi fasilitator jika diperlukan. Selanjutnya siswa diberi kesempatan untuk memberikkan masukkan atau ide-ide merek; (9) meminta siswa untuk mengkomentari jawaban siswa yang mempresentasikan jawabannya di depan kelas; (10) mengarahkan kepada siswa untuk menemukan rumus permutasi dan kombinasi; dan (11) guru mengevaluasi pemahaman siswa jika ada miss concept pada siswa.

Pengamatan

Setlah dilakukan pengamatan setiap pertemuan diperoleh aktivitas belajar siswa seperti pada grafik 1 berikut. 


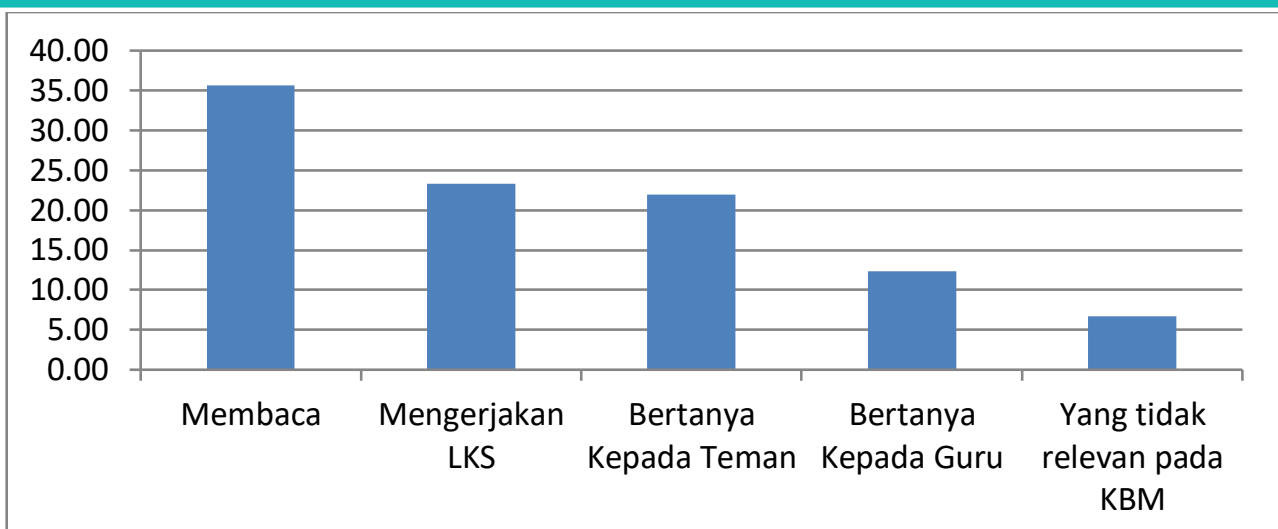

Grafik 1. Hasil Observasi Aktivitas Siswa pada Siklus I

Aktivitas membaca mencapai 35,67\%, sedangkan masih ada siswa melakukan kegiatasn yang tidak relevan dan KBM sebesar 6,67\%. Di samping itu juga diperoleh hasil kemampuan pemecahan masalah matematika siswa, sebagai berikut.

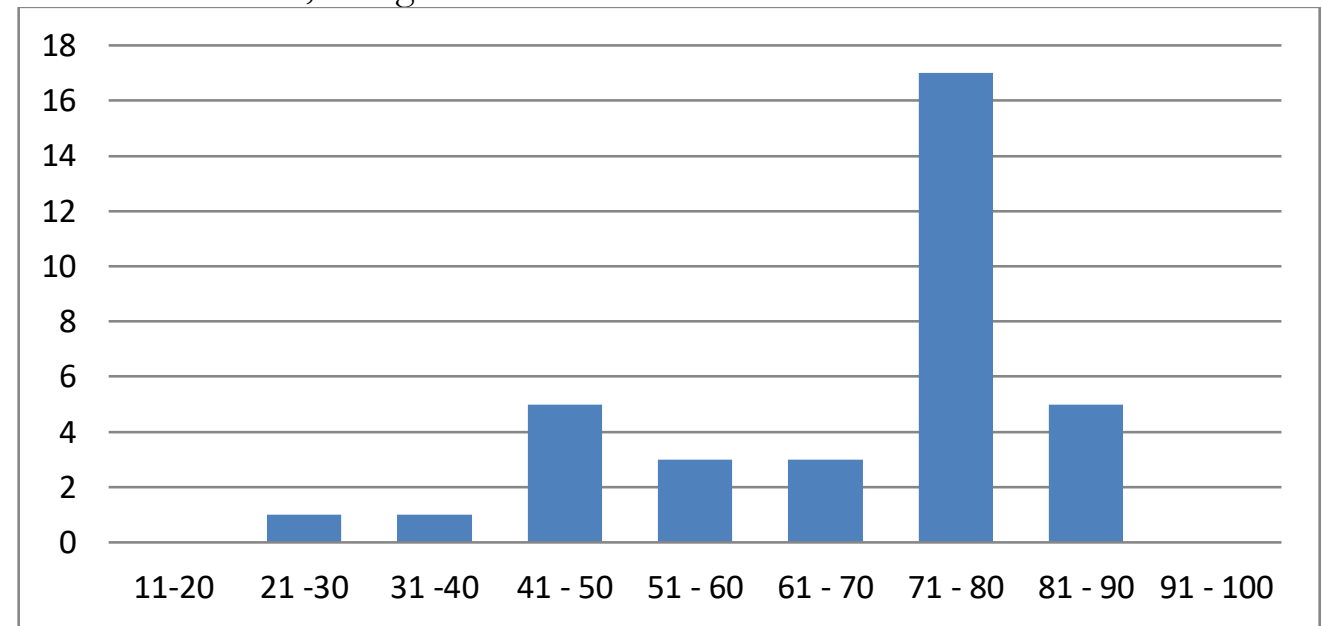

Grafik 2. Kemampuan Pemecahan Masalah Siswa pada Siklus I

Berdasarkan data yang diperoleh pada gambar di atas sebanyak 22 siswa dari 35 siswa seluruhnya telah menuntaskan KKM atau sebesar $62,9 \%$.

\section{Refleksi}

Setelah siklus I selesai, maka peneliti melakukan refleksi yakni melihat kekurangan-kekurangan siklus I diantaranya tidak mencapai ketuntasan klasikal 85\%. Setelah didiskusikan dengan rekan sejawat, maka perlu dilanjutkan pada siklus II.

\section{Deskripsi Siklus II}

Bertolak dari hasil penelitian yang diperoleh pada siklus I, terdapat kelemahan-kelemahan baik dari faktor aktivitas guru maupun kemampuan yang akan dicapai siswa yaitu kemampuan pemecahan masalah matematika siswa serta ketuntasan belajar siswa belum tercapai.

\section{Permasalahan}

Berdasarkan pada hasil tindakan kelas pembelajaran yang diperoleh beberapa hal yang dapat dicatat sebagai masukan untuk perbaikan pada tindakan selanjutnya, yaitu; (1) pembelajaran belum berpusat pada siswa; (2) bimbingan yang diberikan guru kurang menyeluruh; (3) kelompok yang dibentuk guru tidak homogen, karena letak tepat duduk siswa; (4) guru tidak dapat menajemen waktu dengan baik, sehingga semua kegiatan dilakukan secara tergesah-gesah; (5) siswa belum bekerja mengikuti pelaksanaan model pembelajaran secara baik; (6) fungsi kelompok belum bekerja 
Upaya peningkatan kemampuan pemecahan masalah matematika siswa melalui pembelajaran...

dengan baik, siswa bekerja secara individu di dalam kelompok dan melakukan kegiatan yang tidak releva dengan kegiatan belajar mengajar.

\section{Rencana Tindakan}

Untuk memperbaiki dan mempertahankan serta meningkatkan keberhasilan yang telah dicapai pada siklus I, maka pelaksanaan siklus II direncanakan; (1) proses pembelajaran harus berpusat pada siswa yaitu dengan memberian penghargaan tambahan nilai kepada siswa yang aktif berdiskusi dalam kelompok agar masing-masing siswa dalam kelompok saling berpacu; (2) perlu adanya umpan balik bagi siswa agar tahu sejauh mana pemahaman mereka terhadap materi ajar yang di sampaikan; (3) meningkatkan bimbingan siswa secara menyeluruh untuk membantu siswa bekerja secara kelompok dengan benar dan menurunkan persentasi kegiatan yang tidak relevan dengan KBM; (4) mengganti kelompok diskusi siswa menjadi kelompok diskusi yang heterogen, sehingga sswa yang pintas dapat membantu teman sekelompoknya yang kemampuan akademiknya rendah; (5) penggunaan waktu oleh guru yang dialokasikan dengan cermat agar pengerjaan siswa dalam kelompok dapat selesai tepat waktu

\section{Pelaksanaan Tindakan}

Pelaksanaan tindakan terdiri dari dua pertemuan yang tersusun atas; (1) memberikan apersepsi kepada siswa dengan menyampaikan tujuan pembelajaran yang akan dicapai tiap pertemuan; (2) menyajikan informasi kepada siswa melalui Power Point, serta membawakan media pembelajaran seperti dadu atau kartu bridge; (3) saling melempar jawaban antara anggota kelompok; (4) guru membimbing siswa memahami materi ajar melalui tanya jawab mengenai materi peluang suatu kejadian; (5) guru memberikan contoh latihan soal cerita kemudian membimbing siswa menyelesaikannya; (6) menggantikan komposisi kelompok belajara yang lebih heterogen; (7) guru mengevaluasi pemahaman siswa jika ada miss concept pada siswa; (8) guru memberi penghargaan berupa tepuk tangan atau pujian (ucapan) kepada siswa yang menunjukkan kemajuan yang positif

\section{Pengamatan}

Berdasarkan hasil pengamatan aktivitas belajar siswa menunjukkan hasil yang positif. Hasil tersebut dapat dilihat pada grafik di bawah ini.

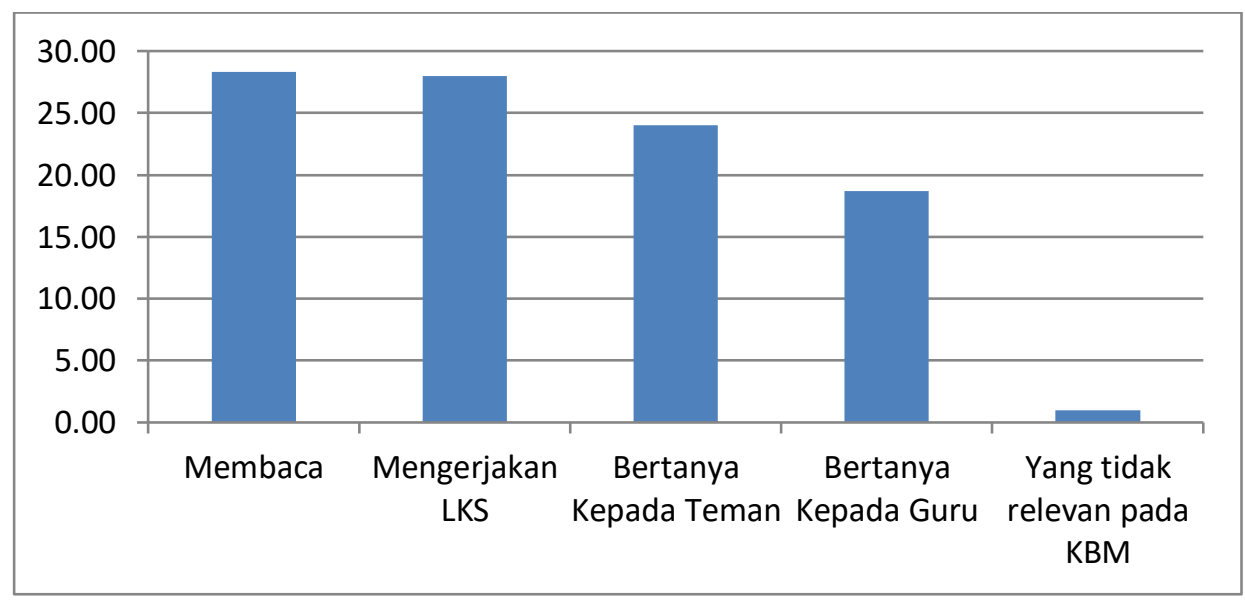

\section{Grafik 3. Hasil Observasi Aktivitas Belajar Siswa pada Siklus II}

Sedangkan untuk kemampuan pemecahan masalah matematika siswa diperoleh seperti pada grafik di bawah ini. 


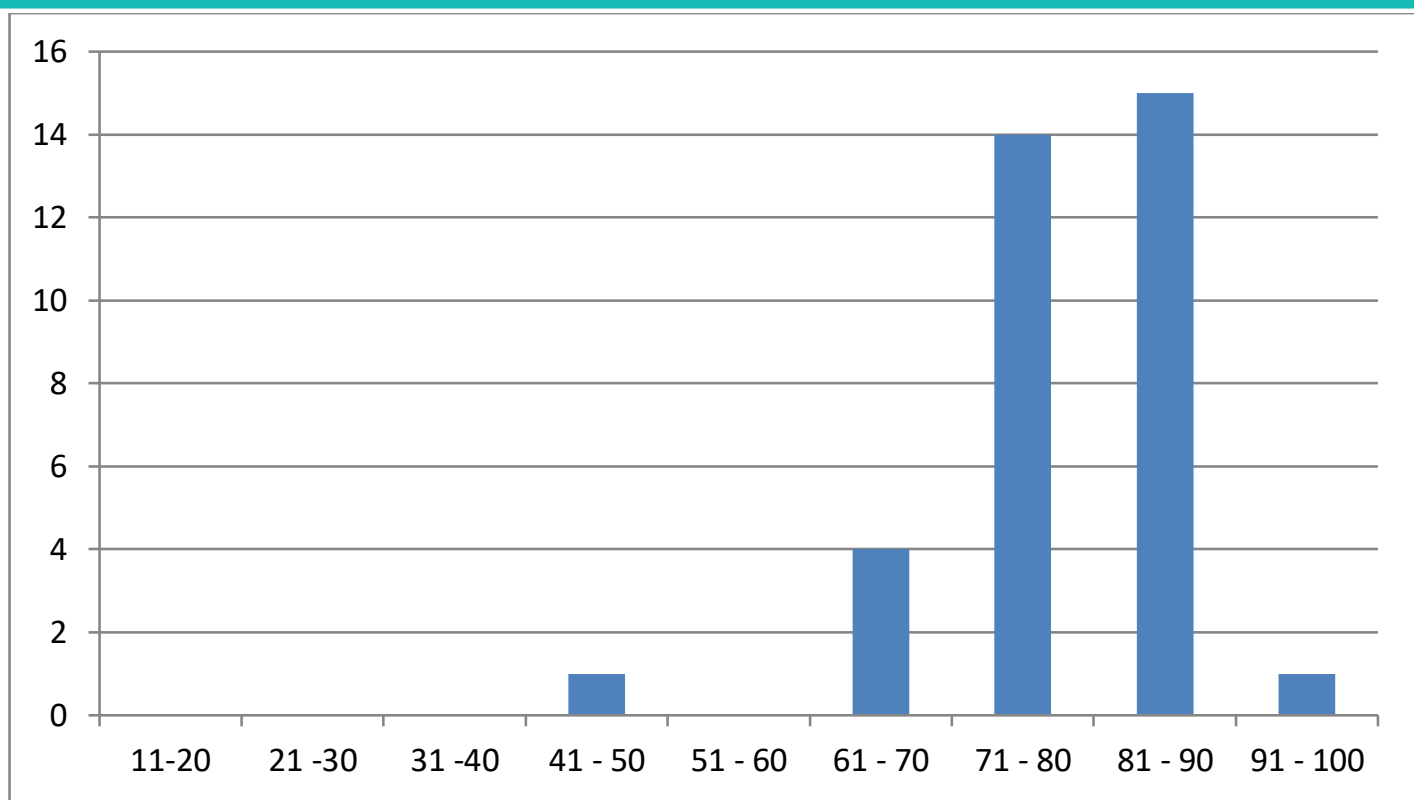

Grafik 4. Hasil Kemampuan Pemecahan Masalah pada siklus II

Hasil di atas menunjukkan bahwa 30 dari 35 siswa atau sekitar (85,7\%) dapat menuntaskan hasil belajarnya. Hal ini juga dapat dilihat peningkatan rata-rata kemampuan pemecahan masalah matematika meningkat dari 67 pada siklus I menjadi 77 pada siklus II artinya meningkat sebesar $12,99 \%$ dari siklus I.

\section{Refleksi}

Dari data yang diperoleh dari siklus II, maka dapat tentukan ketercapaian setiap aspek seperti: aspek kemampuan pemecahan masalah matematika siswa, aspek aktivitas positif terhadap kegiatan belajar mengajar, dan aspek ketuntasan klasikal belajar siswa.

\section{KESIMPULAN}

Berdasarkan hasil penelitian yang diperoleh dari analisis data diperoleh beberapa kesimpulan, data aktivitas siswa menurut pengamat I dan pengamat II pada siklus I antara lain menulis/membaca $(35,67 \%)$, mengerjakan LKS (23,33\%), bertanya kepada sesama teman $(22 \%)$, bertanya guru (12,33\%), dan aktivitas yang tidak relevan dengan kegiatan belajar mengajar (6,67\%) Data aktivitas siswa menurut pengamat pada siklus II antara lain: menulis/membaca $(28,3 \%)$, mengerjakan LKS (28\%), bertanya kepada sesama teman (24\%), bertanya guru $(18,7 \%)$, dan aktivitas yang tidak relevan dengan kegiatan belajar mengajar (1\%). Hasil belajar siswa dengan menerapkan model pembelajaran Contextual Teaching and Learning pada siklus I sampai ke Siklus II mengalami peningkatan pada siklus I nilai rata-rata kemampuan pemecahan masalah matematika 67 dengan ketuntasan klasikal 62,9\% dan pada siklus 2 nilai rata-rata kemampuan pemecahan masalah matematika 77 dengan ketuntasan klasikal 85,7\% sesuai dengan KKM palajaran Mamtematika.

\section{DAFTAR PUSTAKA}

Cai, J., Lane, S., \& Jakabcsin, M.S. (1996). Assesing students mathematical communication. Official Journal of the Science and Mathematics. 96(5), 238-246.

Hudojo, H. (1988). Mengajar belajar matematika. Jakarta: Depdikbud.

Lie, A. (2008). Cooperative learning-mempraktikkean cooperative learning di ruang-ruang kelas. Jakarta: Gramedia. 
Upaya peningkatan kemampuan pemecahan masalah matematika siswa melalui pembelajaran...

NCTM. (2003). Program for Initial Preperation of Mathematics Specialists.
Tersedia:http://www.ncate.org/ProgramStandars/NCTM/NCTMELEMStandars.pdf. [28 April 2015]

Nurhadi. (2002). Pendekatan kontekstual (contextual teaching and learning). Jakarta.

Sanjaya, W. (2006). Strategi pembelajaran berorientasi standar proses pendidikan. Jakarta: Kencana.

Slameto. (2010). Belajar dan faktor-faktor yang mempengarubi. Jakarta: Rineka Cipta.

Sumarmo, U. (2005). Pembelajaran matematika untuk mendukung pelaksanaan kurikulum tabun 2002 sekolah menengah. Gorontalo: Universitas Negeri Gorontalo.

Trianto. (2009). Mendesain model pembelajaran inovatif-progressif: konsep, landasan, dan implementasinya pada kurikulum tingkat satuan pendidikan (KTSP). Jakarta: Kencana.

Turmudi. (2008). Landasan filsafat dan teori pembelajaran matematika. Jakarta: Leuser Cita Pustaka. 